\title{
Asymmetric oxidation of 1,2-diols using $N$-bromosuccinimide in the presence of chiral copper catalyst
}

\author{
Osamu Onomura, Hitomi Arimoto, Yoshihiro Matsumura, and Yosuke Demizu
}

\author{
Graduate School of Biomedical Sciences, Nagasaki University,
}

1-14 Bunkyo-machi, Nagasaki 852-8521, Japan

Dedicated to the memory of the late Professor Yoshihiko Ito

\begin{abstract}
Asymmetric oxidation of 1,2-diols using $N$-bromosuccinimide (NBS) in the presence of copper(II) triflate and $(R, R)$-Ph-BOX has been exploited. This oxidation was applicable to asymmetric desymmetrization of meso-hydrobenzoin and kinetic resolution of $d l$-hydrobenzoin and racemic-cycloalkane-cis-1,2-diols to afford optically active $\alpha$-ketoalcohols with good to high enantiomeric excess.
\end{abstract}

The oxidation of a hydroxyl group into a carbonyl group is a basic and important organic reaction. ${ }^{1}$ Selective oxidation of 1,2-diols to the corresponding $\alpha$-ketoalcohols was reported in 1974 by utilizing a stoichiometric amount of dibutyltinoxide $\left(\mathrm{Bu}_{2} \mathrm{SnO}\right)$ which forms dibutylstannylenes followed by brominolysis, ${ }^{2}$ and the method has been applied to fine chemistry as exemplified by the synthesis of (+)-spectinomycin ${ }^{3}$ and the oxidation of unprotected sugars. ${ }^{4,5}$ From the standpoint of green chemistry, we have recently reported efficient oxidation of 1,2-diols 1 by electrochemical method using a catalytic amount of $\mathrm{Bu}_{2} \mathrm{SnO}$ and bromide ion to afford $\alpha$-ketoalcohols 2 in high yield without 1,2-diketones $\mathbf{3}$ (Eq. 1). ${ }^{6}$ Also, chemical oxidation of $\mathbf{1}$ using $\mathrm{N}$-bromosuccinimide (NBS) (1 equiv) and $\mathrm{Bu}_{2} \mathrm{SnO}$ (0.1 equiv) in the presence of $\mathrm{K}_{2} \mathrm{CO}_{3}$ ( 1 equiv) proceeded to afford $2 .^{7}$ To the best of our knowledge, catalytic asymmetric oxidation $^{8}$ of $\mathbf{1}$ to $\mathbf{2}$ has not been known except for two examples using semi-catalytic amount of chiral dioxiranes ${ }^{9}$ or chiral hypervalent iodine. ${ }^{10}$

Key words: Asymmetric oxidation; vic-Diol; $\alpha$-Ketoalcohol, Copper complex

* Corresponding author, Tel +81-95-819-2429, Fax +81-95-819-2476, E-mail onomura@nagasaki-u.ac.jp (O. Onomura) 
<smiles>[R]C(O)C([R])O</smiles>

$-2 e$

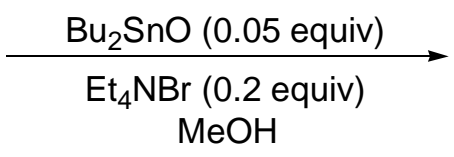

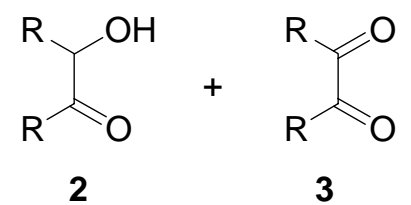

up to $96 \%$ yield $\quad \sim 0 \%$

We wish to report herein a catalytic asymmetric oxidation of (meso or $d l$ )-1,2-diols meso- or $d l-1$, or cis-1,2-diols 4 to afford the corresponding optically active $\alpha$-ketoalcohols chiral-2 or chiral-6 in good to high yield and enantioselectivity, which is based on recognition of the diol-moiety by a copper(II) ion associated with $(R, R)-\mathrm{Ph}-\mathrm{BOX}$ complex ${ }^{11,12}$ to form the activated intermediates 5 followed by oxidation with $\mathrm{NBS}^{13}$ as an oxidant (Eq. 2).

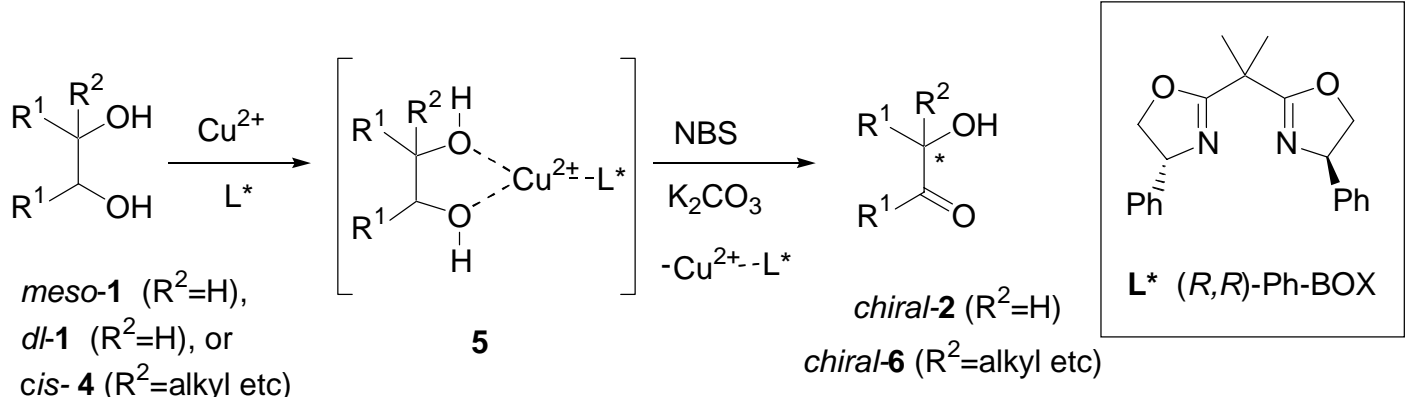

We began by trying an oxidation of meso-hydrobenzoin (meso-1a) using NBS as an oxidant to see whether meso-1a was recognized by the $\mathrm{Cu}(\mathrm{II})-(R, R)-\mathrm{Ph}-\mathrm{BOX}$ complex under the above stated oxidation condition or not. The oxidation of meso-1a in the presence of $\mathrm{Cu}(\mathrm{OTf})_{2}$ and $(R, R)$-Ph-BOX predominantly afforded mono-oxidized product 2a (83\% yield) along with small amount of di-oxidized product 3a (17\% yield), while there was almost no oxidation in the absence of $\mathrm{Cu}(\mathrm{OTf})_{2}$ and $(R, R)-\mathrm{Ph}-\mathrm{BOX}(\mathrm{Eq}$. $3)$. These results suggested that meso-1a is recognized by the $\mathrm{Cu}(\mathrm{II})-(R, R)-\mathrm{Ph}-\mathrm{BOX}$ complex under these oxidation conditions. Acceleration of the oxidation was also observed in the presence of $\mathrm{Cu}(\mathrm{OTf})_{2}$ without $(R, R)-\mathrm{Ph}-\mathrm{BOX}$ to afford $\mathbf{2 a}$ in high yield $(91 \%) .^{14}$ 
<smiles>OC(c1ccccc1)C(O)c1ccccc1</smiles>

meso-1a

in the presence of $\mathrm{Cu}(\mathrm{OTf})_{2}$ (0.1 equiv) and

$(R, R)-\mathrm{Ph}-\mathrm{BOX}$ ( 0.1 equiv)

in the presence of $\mathrm{Cu}(\mathrm{OTf})_{2}$ ( 0.1 equiv)

in the absence of $\mathrm{Cu}(\mathrm{OTf})_{2}$ and

$(R, R)$-Ph-BOX<smiles>O=C(c1ccccc1)C(O)c1ccccc1</smiles>

2a

$83 \%$

$91 \%$

$4 \%$<smiles>O=C(C(=O)c1ccccc1)c1ccccc1</smiles>

3a

$17 \%$

$9 \%$

$0 \%$

Then, we tried competitive reaction between diol meso-1a and monool 7 (Eq. 4). In the absence of $\mathrm{Cu}(\mathrm{OTf})_{2}$ and $(R, R)-\mathrm{Ph}-\mathrm{BOX}$, meso-1a and 7 were oxidized to $2 \mathbf{a}$ and $\mathbf{8}$ with almost same ratio. On the other hand, in the presence of $\mathrm{Cu}(\mathrm{II})-(R, R)-\mathrm{Ph}-\mathrm{BOX}, \mathbf{2 a}$ was predominantly obtained. This result indicates that meso-1,2-diol was more preferentially-recognized with the $\mathrm{Cu}(\mathrm{II})-(R, R)-\mathrm{Ph}-\mathrm{BOX}$ catalyst than monool.

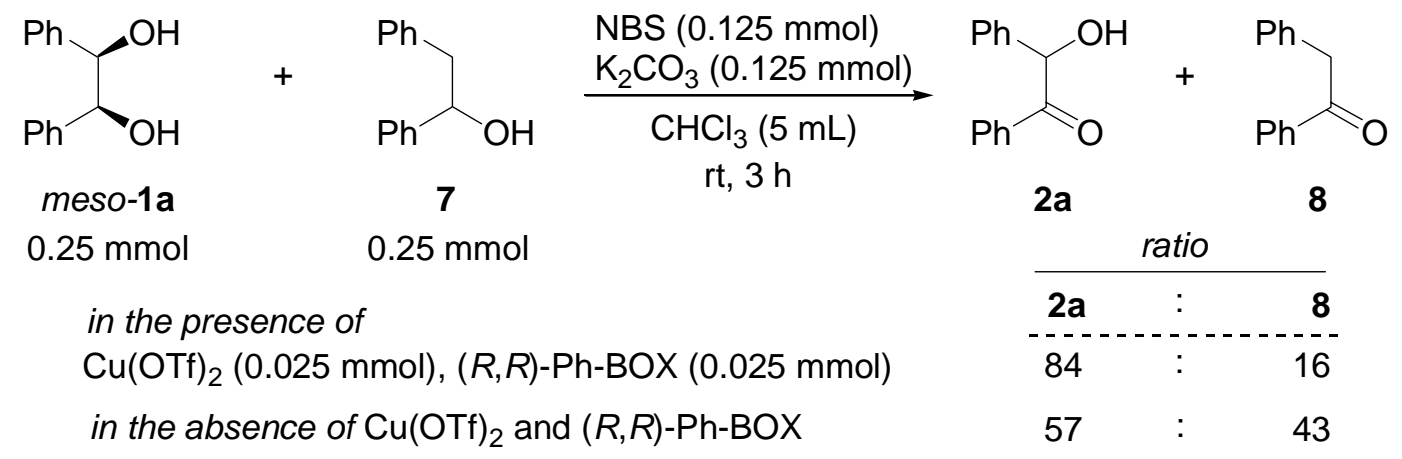

Next, we investigated effect of solvents and bases so as to optimize reaction conditions for the asymmetric oxidation of meso-1a (Eq. 5). ${ }^{15}$ The results are summarized in Table 1. $\mathrm{CHCl}_{3}$ is the best solvent for the reaction in terms of enantiomeric excess (entry 1). $\mathrm{CH}_{2} \mathrm{Cl}_{2}$, THF, $\mathrm{CH}_{3} \mathrm{CN}$ and AcOEt give high yield of product $(R)$-2a although the enantioselectivity is very low or sometime racemic mixture (entries2-5). $\mathrm{MeOH}$ gives very low yield with moderate enantioselectivity (entry 6). In the case of bases, $\mathrm{K}_{2} \mathrm{CO}_{3}$ emerged as the best base especially when used in combination with $\mathrm{CHCl}_{3}$ (entry 1). $\mathrm{Na}_{2} \mathrm{CO}_{3}$ and $\mathrm{NaHCO}_{3}$ give comparable results to that of $\mathrm{K}_{2} \mathrm{CO}_{3}$ (entries 8 and 9). Other bases fall short in terms of yield or enantioselectivity (entries $7,10,11$ ). 


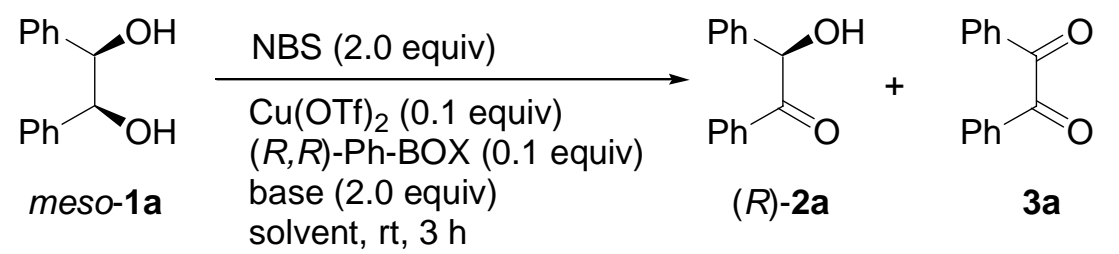

Table 1. Asymmetric oxidation of meso-hydrobenzoin (meso-1a) ${ }^{\mathrm{a}}$

\begin{tabular}{|c|c|c|c|c|c|}
\hline \multirow[t]{2}{*}{ Entry } & \multirow[t]{2}{*}{ Solvent } & \multirow[t]{2}{*}{ Base } & \multicolumn{2}{|c|}{$(R)-\mathbf{2 a}$} & \multirow{2}{*}{$\begin{array}{c}\mathbf{3 a} \\
\text { Yield (\%) }\end{array}$} \\
\hline & & & Yield (\%) & ee $(\%)^{b}$ & \\
\hline 1 & $\mathrm{CHCl}_{3}$ & $\mathrm{~K}_{2} \mathrm{CO}_{3}$ & 83 & 72 & 17 \\
\hline 2 & $\mathrm{CH}_{2} \mathrm{Cl}_{2}$ & $\mathrm{~K}_{2} \mathrm{CO}_{3}$ & 92 & 26 & 8 \\
\hline 3 & THF & $\mathrm{K}_{2} \mathrm{CO}_{3}$ & 87 & 29 & 13 \\
\hline 4 & $\mathrm{CH}_{3} \mathrm{CN}$ & $\mathrm{K}_{2} \mathrm{CO}_{3}$ & 88 & 0 & 12 \\
\hline 5 & AcOEt & $\mathrm{K}_{2} \mathrm{CO}_{3}$ & 87 & 23 & 13 \\
\hline 6 & $\mathrm{MeOH}$ & $\mathrm{K}_{2} \mathrm{CO}_{3}$ & 9 & 46 & 25 \\
\hline 7 & $\mathrm{CHCl}_{3}$ & $\mathrm{Li}_{2} \mathrm{CO}_{3}$ & 88 & 59 & 12 \\
\hline 8 & $\mathrm{CHCl}_{3}$ & $\mathrm{Na}_{2} \mathrm{CO}_{3}$ & 96 & 66 & 4 \\
\hline 9 & $\mathrm{CHCl}_{3}$ & $\mathrm{NaHCO}_{3}$ & 91 & 67 & 9 \\
\hline 10 & $\mathrm{CHCl}_{3}$ & $\mathrm{KOH}$ & 79 & 29 & 21 \\
\hline 11 & $\mathrm{CHCl}_{3}$ & 2,6-lutidine & 97 & 15 & 3 \\
\hline
\end{tabular}

${ }^{a}$ meso-1a $(0.5 \mathrm{mmol}), \mathrm{Cu}(\mathrm{OTf})_{2}(0.05 \mathrm{mmol}),(R, R)-\mathrm{Ph}-\mathrm{BOX}(0.05 \mathrm{mmol}), \mathrm{NBS}$ $(1.0 \mathrm{mmol})$, base $(1.0 \mathrm{mmol})$ in a solvent $(5.0 \mathrm{~mL})$ at $\mathrm{rt}$ for $3 \mathrm{~h}$.

${ }^{\mathrm{b}}$ Determined by HPLC.

Utilizing the conditions optimized in Table 1, we screened other halogen compounds as oxidants in this reaction (Eq. 6). The results are shown in Table 2. In addition to NBS, $\mathrm{N}$-bromophthalimide (entry 4) was usable for asymmetric oxidation, while other oxidants (entries 1-3) were less effective. The use of 1.5 equiv of NBS or $N$-bromophthalimide gave $(R)-\mathbf{2 a}$ in high yield and moderate enantioselectivity, respectively (entries 6 and 8). Using 1.5 equiv of $\mathrm{NBS}, 0.05$ or 0.2 equiv of $\mathrm{Cu}(\mathrm{OTf})_{2}$ and $(R, R)$-Ph-BOX afforded almost similar results to that using 0.1 equiv of chiral $\mathrm{Cu}$ (II) catalyst (entries 9 and 10). Whereas using 0.01 equiv of chiral $\mathrm{Cu}(\mathrm{II})$ catalyst slightly reduced the enantioselectivity (entry 11 ), use of the same amount of $\mathrm{Cu}(\mathrm{OTf})_{2}$ and slightly excess amount of $(R, R)-\mathrm{Ph}-\mathrm{BOX}$ was effective (entry 12$)$. In case of using 0.1 equiv of $\mathrm{Cu}(\mathrm{OTf})_{2}$, varying the amounts of $(R, R)-\mathrm{Ph}-\mathrm{BOX}$ showed no effect on the yields and the enantioselectivities (entries 13 and 14). 


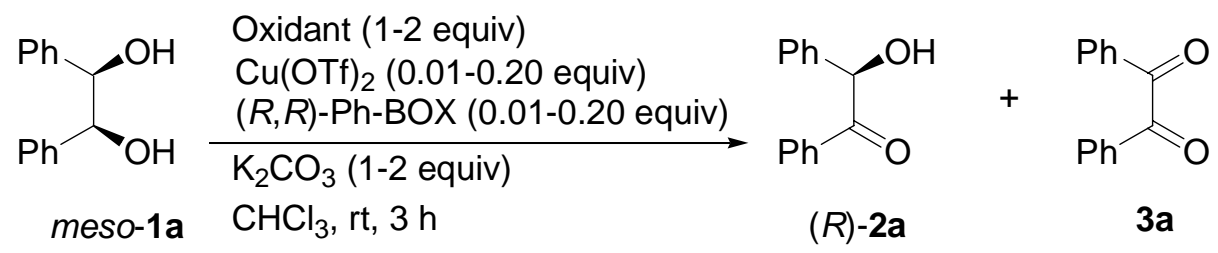

Table 2. Oxidation of meso-1a by some oxidants ${ }^{\mathrm{a}}$

\begin{tabular}{llcccccr}
\hline \multirow{2}{*}{ Entry } & \multirow{2}{*}{ Oxidant } & $\begin{array}{c}\text { Equiv of } \\
\text { oxidant }\end{array}$ & $\begin{array}{c}\text { Equiv of } \\
\text { Cu(OTf) }\end{array}$ & $\begin{array}{c}\text { Equiv of } \\
(R, R) \text {-Ph-BOX }\end{array}$ & \multicolumn{2}{c}{$(R)$-2a } & \multicolumn{2}{c}{ 3a } \\
\cline { 7 - 8 } \cline { 5 - 6 } & NCS & 2.0 & 0.1 & 0.1 & 26 & 6 & 2 \\
2 & NIS & 2.0 & 0.1 & 0.1 & 88 & 9 & 10 \\
3 & $\mathrm{Br}_{2}$ & 2.0 & 0.1 & 0.1 & 59 & 43 & 5 \\
4 & N-Bromophthalimide & 2.0 & 0.1 & 0.1 & 72 & 71 & 28 \\
5 & NBS & 1.0 & 0.1 & 0.1 & 63 & 67 & 2 \\
6 & NBS & 1.5 & 0.1 & 0.1 & 94 & 70 & 6 \\
7 & N-Bromophthalimide & 1.0 & 0.1 & 0.1 & 91 & 69 & 0 \\
8 & N-Bromophthalimide & 1.5 & 0.1 & 0.1 & 97 & 76 & 3 \\
9 & NBS & 1.5 & 0.2 & 0.2 & 96 & 69 & 4 \\
10 & NBS & 1.5 & 0.05 & 0.05 & 94 & 68 & 6 \\
11 & NBS & 1.5 & 0.01 & 0.01 & 96 & 63 & 4 \\
12 & NBS & 1.5 & 0.01 & 0.012 & 94 & 69 & 6 \\
13 & NBS & 1.5 & 0.1 & 0.12 & 93 & 70 & 7 \\
14 & NBS & 1.5 & 0.1 & 0.2 & 95 & 69 & 2 \\
\hline
\end{tabular}

a meso-1a (0.5 mmol), oxidant (0.5-1.0 mmol), Cu(OTf) 2 (0.005-0.1 mmol), $(R, R)-\mathrm{Ph}-\mathrm{BOX}$ (0.005-0.1 mmol), $\mathrm{K}_{2} \mathrm{CO}_{3}$ (1.0 equiv to oxidant) in $\mathrm{CHCl}_{3}(5.0 \mathrm{~mL})$ at $\mathrm{rt}$ for $3 \mathrm{~h}$.

${ }^{\mathrm{b}}$ Determined by HPLC.

Then, we applied this methodology to the kinetic resolution of cis-cyclohexane-1,2-diol derivative 4ap (Eq. 7). Compound 4ap was enantioselectively oxidized with NBS and the $\mathrm{Cu}(\mathrm{II})-(R, R)-\mathrm{Ph}-\mathrm{BOX}$ complex to afford $\alpha$-ketoalcohol $(S)$-6ap ${ }^{17}$ with moderate yield $(30 \%)$ and selectivity $(s)$ value of $14 .^{19}$
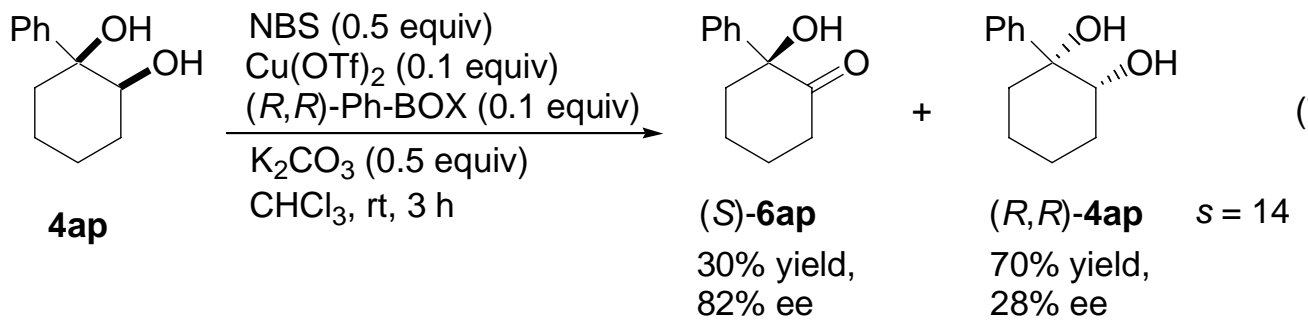

Asymmetric oxidation of other cycloalkane-cis-1,2-diols 4bp-at is summarized in Table 3 (Eq. 8). ${ }^{20}$ The chemical yield of $6 \mathbf{b p - d p}$ and $s$ value varied significantly depending on 
the ring size. That is, the larger the ring size, the better the yield and $s$ value obtained (entries 1-3). R substituent also influenced the $s$ value (entries 4-7). Compound 4at with a cyclohexyl substituent was asymmetrically oxidized to afford 6at in higher enantioselectivity ( $85 \%$ ee, entry 7) than 6aq with a methyl substituent (5\% ee, entry 4), 6ar with an isopropyl substituent (74\% ee, entry 5) and 6as with a benzyl substituent (48\% ee, entry 6$)$.

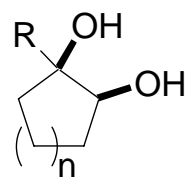

4bp-at

$$
\begin{aligned}
& \mathrm{NBS}(0.5 \text { equiv) } \\
& \mathrm{Cu}(\mathrm{OTf})_{2}(0.1 \text { equiv }) \\
& \stackrel{(R, R)-\mathrm{Ph}-\mathrm{BOX}(0.1 \text { equiv })}{\longrightarrow} \mathrm{K}_{2} \mathrm{CO}_{3}(0.5 \text { equiv })
\end{aligned}
$$

$\mathrm{CHCl}_{3}, \mathrm{rt}, 3 \mathrm{~h}$<smiles>[R]C1(O)CCCCC1=O</smiles>

(S)-6bp-at<smiles>[R][C@]1(O)CCCC[C@@H]1O</smiles>

$(R, R)$-4bp-at

\begin{tabular}{|c|c|c|c|c|c|c|c|c|c|}
\hline \multirow{2}{*}{\multicolumn{2}{|c|}{ Entry }} & \multirow{2}{*}{$\mathrm{n}$} & \multirow{2}{*}{$\mathrm{R}$} & \multicolumn{3}{|c|}{$\alpha$-Ketoalcohol } & \multicolumn{2}{|c|}{ Recovered diol } & \multirow{2}{*}{$S$} \\
\hline & & & & Yielc & $(\%)$ & ee $(\%)^{b}$ & Yield (\%) & ee $(\%)^{b}$ & \\
\hline 1 & $4 b p$ & 1 & $\mathrm{Ph}$ & $6 b p$ & 23 & 76 & 77 & 24 & 9 \\
\hline 2 & $4 c p$ & 3 & $\mathrm{Ph}$ & $6 c p$ & 35 & 84 & 65 & 30 & 15 \\
\hline 3 & $4 d p$ & 4 & $\mathrm{Ph}$ & $6 \mathrm{dp}$ & 42 & 82 & 58 & 58 & 18 \\
\hline 4 & $4 a q$ & 2 & $\mathrm{Me}$ & $6 a q$ & 32 & 5 & 68 & $N D^{C}$ & - \\
\hline 5 & $4 a r$ & 2 & iPr & 6ar & 30 & 74 & 70 & $45^{d}$ & 10 \\
\hline 6 & 4as & 2 & $\mathrm{Bn}$ & 6as & 33 & 48 & 67 & 32 & 4 \\
\hline 7 & 4at & 2 & $C y^{e}$ & 6at & 29 & 85 & 67 & $48^{d}$ & 19 \\
\hline
\end{tabular}

Table 3. Asymmetric oxidation of cis-1,2-diols (4bp-at) ${ }^{\mathrm{a}}$

a 4bp-at $(0.5 \mathrm{mmol}), \mathrm{Cu}(\mathrm{OTf})_{2}(0.05 \mathrm{mmol}),(R, R)$-Ph-BOX (0.05 mmol), NBS (0.25 $\mathrm{mmol}), \mathrm{K}_{2} \mathrm{CO}_{3}(0.25 \mathrm{mmol})$ in $\mathrm{CHCl}_{3}(5.0 \mathrm{~mL})$ at rt for $3 \mathrm{~h}$.

${ }^{b}$ Determined by HPLC using chiral columns: Daicel Chiralcel OJ-H for $\mathbf{4 b p}, \mathbf{4 c p}$, 4as, 6bp, 6cp, 6dp; Chiralpak AS for 4dp, 4ar, ${ }^{d}$ 6ar; Chiralpak AD for 4at, ${ }^{d}$ 6as, 6at; Chiralcel OC for 6ap.

${ }^{c}$ Not determined.

${ }^{d}$ Ee of the corresponding 2-phenylcarbamoylated compound.

e Cyclohexyl.

This method was then applied to the kinetic resolution of $d l$-hydrobenzoin $(d l-1 \mathbf{a})$, where $(S)$-benzoin $((S)$-2a) was obtained with $43 \%$ yield and $73 \%$ ee (Eq. 9). 


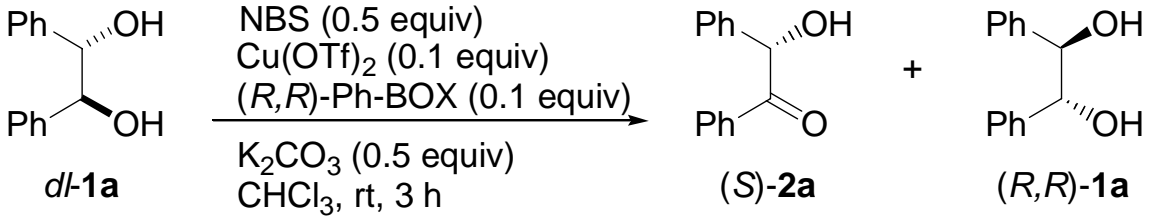

$$
\begin{aligned}
& 43 \% \text { yield, } \quad 55 \% \text { yield, } \quad s=12 \\
& 73 \% \text { ee } \quad 60 \% \text { ee }
\end{aligned}
$$

Scheme 1 shows our proposed mechanism for asymmetric oxidation of meso-1a catalyzed by $\mathrm{Cu}(\mathrm{II})-(R, R)-\mathrm{Ph}-\mathrm{BOX}$. Possibly, $\mathrm{Br}^{+}$approaches the less crowded alkoxide $\mathrm{O}_{\mathbf{A}}$ compared with $\mathrm{O}_{\mathbf{B}}$ of the activated intermediate meso-5a which is generated from $1 \mathbf{a}$ with $\mathrm{Cu}(\mathrm{II})-(R, R)-\mathrm{Ph}-\mathrm{BOX}$, to afford $(R)-\mathbf{2 a}$.

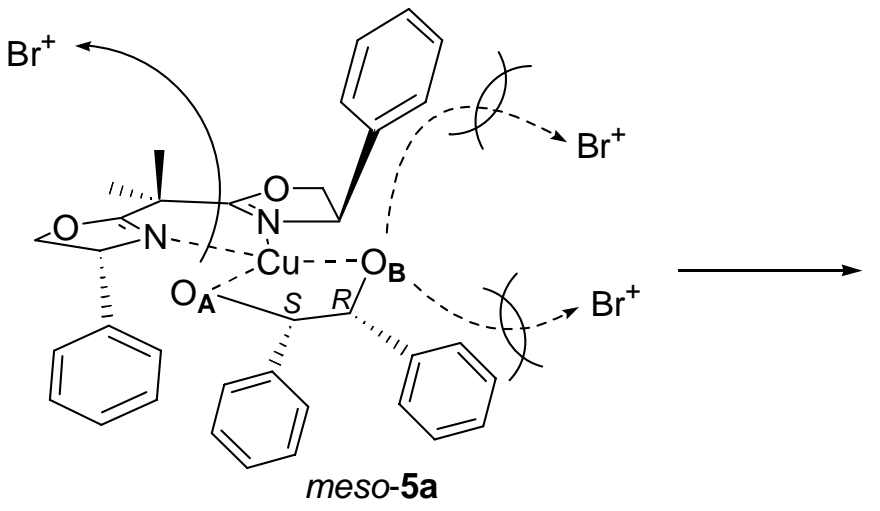<smiles>O=C(c1ccccc1)c1ccccc1</smiles>

Scheme 1. Plausible stereochemical course for desymmetrization of meso-1a.

Scheme 2 shows our proposed mechanism for kinetic resolution of $d l$-1a catalyzed by $\mathrm{Cu}(\mathrm{II})-(R, R)-\mathrm{Ph}-\mathrm{BOX}$. Although the activated intermediate $(R, R)-\mathbf{5 a}$ might be formed more easily than $(S, S)-\mathbf{5 a}, \mathrm{Br}^{+}$predominantly approaches the less crowded intermediate $(S, S)$-5a to afford $(S)$-2a. 


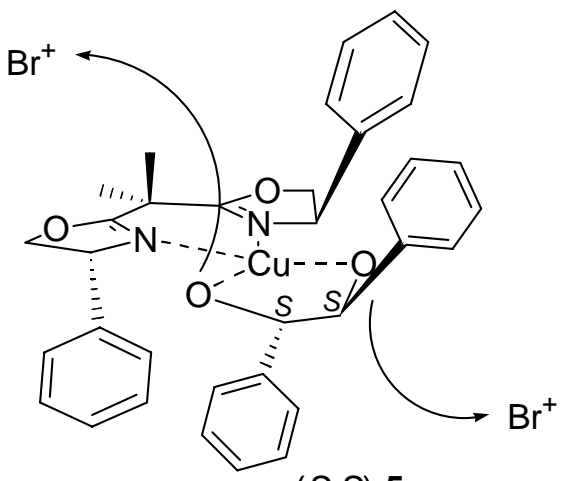

$(S, S)-5 a$

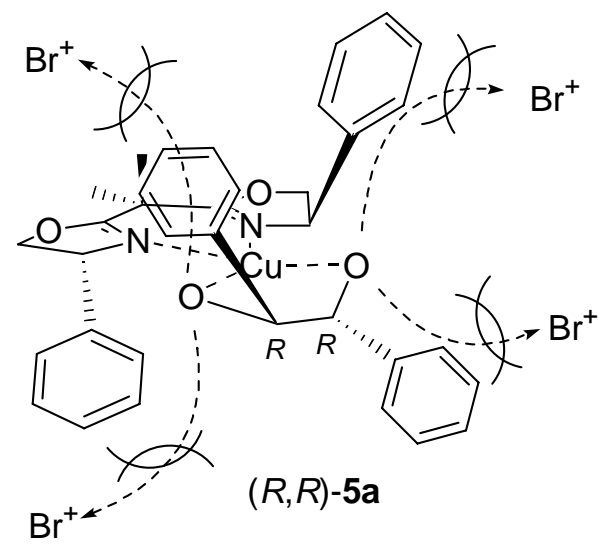

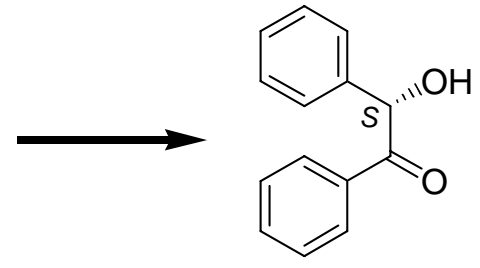

$(S)-2 a$

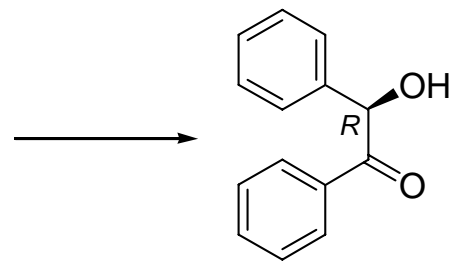

$(R)-2 a$

Scheme 2. Plausible stereochemical course for kinetic resolution of $d l-1 a$.

The results presented in this communication are novel for asymmetric oxidation of 1,2-diols to afford enantiomerically enriched $\alpha$-ketoalcohols. Its synthetic application and mechanistic study are underway.

\section{Acknowledgements}

This study was supported by a Grant-in-Aid for Scientific Research (B) (No. 17350051) from Japan Society for the Promotion of Science.

\section{References and notes}

1. Recent reviews: (a) Noyori, R.; Aoki, M.; Sato, K. Chem. Commun. 2003, 1977-1986. (b) Irie, R.; Katsuki, T. Chemical Record 2004, 4, 96-109. (c) Mallat, T.; Baiker, A. Chem. Rev. 2004, 104, 3037-3058. (d) Schultz, M. J.; Sigman, M. S. Tetrahedron 2006, 62, 8227-8241.

2. (a) David, S. C. R. Acad. Sci. Paris, Serie C 1974, 278, 1051-1053. (b) David, S.; Theffry, A. J. Chem. Soc. Perkin 1 1979, 1568-1573. 
3. Hanessian, S.; Roy, R. J. Am. Chem. Soc. 1979, 101, 5839-5841.

4. (a) Tsuda, Y.; Hanajima, M.; Yoshimoto, K. Chem. Pharm. Bull. 1983, 31, 3778-3788. (b) Tsuda, Y.; Hanajima, M.; Matsuhira, N.; Okuno, Y.; Kanemitsu, K. Chem. Pharm. Bull. 1989, 37, 2344-2350. (c) Liu, H. M.; Sato, Y.; Tsuda, Y. Chem. Pharm. Bull. 1993, 41, 491-501.

5. Fernandez-Mayoralas, A.; Bernabe, M.; Martin-Lomas, M. Tetrahedron 1988, 44, 4877-4882.

6. Maki, T.; Fukae, K.; Harasawa, H.; Ohishi, T.; Matsumura, Y.; Onomura, O. Tetrahedron Lett. 1998, 39, 651-654.

7. Reaction conditions: in $\mathrm{CHCl}_{3}$, at $\mathrm{rt}$, for $3 \mathrm{~h}$; from meso-hydrobenzoin (1a) to benzoin (2a) in $65 \%$ and benzil (3a) in $18 \%$ yield.

8. Representative literatures for catalytic asymmetric oxidation of 1,3- and/or 1,4-diols: (a) Ferreira, E. M.; Stoltz, B. M. J. Am. Chem. Soc. 2001, 123, 7725-7726.

(b) Tanaka, H.; Kawakami, Y.; Goto, K.; Kuroboshi, M. Tetrahedron Lett. 2001, 42, 445-448. (c) Kashiwagi, Y.; Kurushima, F.; Chiba, S.; Anzai, J.; Osa, T.; Bobbitt, J. M. Chem. Commun. 2003, 114-115. (d) Mandal, S. K.; Sigman, M. S. J. Org. Chem. 2003, 68, 7535-7537. (e) Suzuki, T.; Morita, K.; Matsuo, Y.; Hiroi, K. Tetrahedron Lett. 2003, 44, 2003-2006. (f) Shimizu, H.; Onitsuka, S.; Egami, H.; Katsuki, T. J. Am. Chem. Soc. 2005, 127, 5396-5413. (g) Nakamura, Y.; Egami, H.; Matsumoto, K.; Uchida, T.; Katsuki, T. Tetrahedron 2007, 63, 6383-6387.

9. (a) Jakka, K.; Zhao, C-. G. Org. Lett. 2006, 8, 3013-3015. Stoichiometric method; (b) D'Accolti, L.; Detomaso, A.; Fusco, C.; Rosa, A.; Curci, R. J. Org. Chem. 1993, 58, 3600-3601. (c) Adam, W.; Saha-Möller, C. R.; Zhao, C-. G. J. Org. Chem. 1999, 64, 7492-7497.

10. Ladziata, U.; Carlson, J.; Zhdankin, V. V. Tetrahedron Lett. 2006, 47, 6301-6304.

11. Some of asymmetric reactions catalyzed with $\mathrm{Cu}(\mathrm{II})-\mathrm{Ph}-\mathrm{BOX}$ reported by us: Monobenzoylation of 1,2-diols; (a) Matsumura, Y.; Maki, T.; Murakami, S.; Onomura. O. J. Am. Chem. Soc. 2003, 125, 2052-2053. Monocarbamoylation of 1,2-diols; (b) Matsumoto, K.; Mitsuda, M.; Ushijima, N.; Demizu, Y.; Onomura, O.; Matsumura, Y. Tetrahedron Lett. 2006, 47, 8453-8456. Monosulfonylation of 1,2-diols; (c) Demizu, Y.; Matsumoto, K.; Onomura, O.; Matsumura, Y. Tetrahedron Lett. 2007, 48, 7605-7609. Benzoylation of 2-aminoalcohols; (d) Mitsuda, M.; Tanaka, T.; Tanaka, T.; Demizu, Y.; Onomura, O.; Matsumura, Y. Tetrahedron Lett. 2006, 47, 8073-8077. Alkylation into iminium ions; (e) Matsumura, Y.; Minato, D.; Onomura, O. J. Organomet. Chem. 2007, 692, 654-663.

12. A recent review of chiral bis(oxazoline) ligands: Desimoni, G.; Faita, G.; Jørgensen, 
K. A. Chem. Rev. 2006, 106, 3561-3651.

13. Recently, oxidation of 1,2-diols to 1,2-diketones using NBS as an oxidant has been reported: Khurana, J. M.; Kandpal, B. M. Tetrahedron Lett. 2003, 44, 4909-4912.

14. The activated intermediates 5 are transformed by $\mathrm{K}_{2} \mathrm{CO}_{3}$ to the copper(II) alkoxide, ${ }^{11 \mathrm{a}}$ which might be more easily oxidized than the corresponding diols.

15. A typical procedure for asymmetric oxidation: Under an aerobic atmosphere, a solution of $\mathrm{Cu}(\mathrm{OTf})_{2}(18.1 \mathrm{mg}, 0.05 \mathrm{mmol})$ and $(R, R)-\mathrm{Ph}-\mathrm{BOX}(16.7 \mathrm{mg}, 0.05$ $\mathrm{mmol})$ in $\mathrm{CHCl}_{3}(5 \mathrm{~mL})$ was stirred for $10 \mathrm{~min}$. Into the solution were added $\mathbf{1 a}(0.5$ $\mathrm{mmol}$ ), potassium carbonate $(138 \mathrm{mg}, 1.0 \mathrm{mmol})$ and NBS $(178 \mathrm{mg}, 1.0 \mathrm{mmol})$. After stirring for $3 \mathrm{~h}$ at $\mathrm{rt}$, the solution was poured in $10 \%$ aqueous $\mathrm{Na}_{2} \mathrm{~S}_{2} \mathrm{O}_{3}$ and extracted with AcOEt (20 mL x 3). The combined organic layer was dried over $\mathrm{MgSO}_{4}$ and the solvent was removed under reduced pressure. The residue was purified by silica gel column chromatography $(n$-hexane : AcOEt $=15: 1)$ to afford $(R)-\mathbf{2 a}\left(83 \%\right.$ yield, $72 \%$ ee) as a white solid. m.p. $135-137{ }^{\circ} \mathrm{C} .[\alpha]^{26}{ }_{\mathrm{D}}-77.7(c 1.5$, acetone) $\left[\right.$ lit. $^{16}(S)-2 \mathbf{a}\left(>98 \%\right.$ ee); $[\alpha]_{\mathrm{D}}^{22}+111.9$ (c 1.5, acetone)]. The optical purity of $(R)$-2a was determined by chiral HPLC: Daicel Chiralcel OJ-H column $(4.6 \mathrm{~mm}$ $\phi, 250 \mathrm{~mm}), n$-hexane : isopropanol $=10: 1$, wavelength: $210 \mathrm{~nm}$, flow rate: 1.0 $\mathrm{ml} / \mathrm{min}$, retention time: $20.5 \min ((R)-(+)-\mathbf{2 a}), 24.5 \min ((S)-(-)-\mathbf{2 a})$.

16. The absolute configuration of $(R)$-2a was determined by comparing with specific rotation of authentic sample. Demir, A. S.; Şeşenoglu, Ö. Org. Lett. 2003, 5, 2047-2050.

17. The absolute stereoconfiguration of recovered $(R, R)$-4ap was determined by comparing with specific rotation of authentic sample. Compound $(R, R)-\mathbf{4 a p}:[\alpha]^{25}$ -3.5 (c 1.2, EtOH). [lit. ${ }^{18}(R, R)-4 a p\left(>99 \%\right.$ ee); $\left.[\alpha]^{25}{ }_{\mathrm{D}}-7.1(c 1.2,95 \% \mathrm{EtOH})\right]$

18. Huang, J.; Corey, E. J. Org. Lett. 2003, 5, 3455-3458.

19. Kagan, H. B.; Fiaud, J. C. Topics in Stereochemistry; Eliel, E. L., Ed.; Wiley \& Sons: New York, 1988, Vol. 18, 249-330.

20. Absolute stereoconfiguration of $\mathbf{6 b p}-\mathbf{a t}$ shown in Eq. 8 and Table 3 was deduced on the basis of that of $6 \mathbf{a p}$. 
Graphical Abstract

To create your abstract, type over the instructions in the template box below.

Fonts or abstract dimensions should not be changed or alt

Asymmetric oxidation of 1,2-diols using $N$-bromo-

Leave this area blank for abstract info. succinimide in the presence of chiral copper catalyst

Osamu Onomura, ${ }^{*}$ Hitomi Arimoto, Yoshihiro Matsumura, Yosuke Demizu
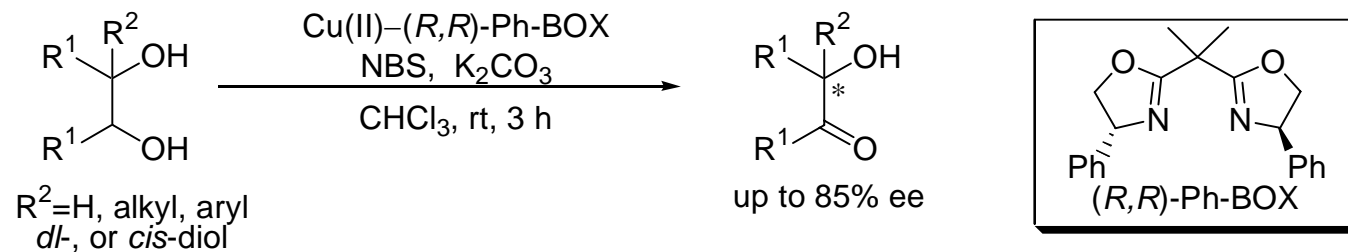